Lowering of cholesterol to reduce the rate of IHD has been associated with increased deaths from suicide and accidents (Engelberg, 1992). Elliott (Journal, June 1993, 162, 818-825) suggests that the overall result of diminished brain cholesterol would be reduced 5-HT (serotonin) activity by increased pre-synaptic 5-HT uptake or decreased post-synaptic transmission.

A lowering of total plasma cholesterol on recovery from depression might therefore inhibit the facilitation of 5-HT transmission generally considered to be the result of antidepressant treatment, if it were mirrored in the brain, but the cholesterol content of HDL may be more important for brain function. In our study there was no significant change in HDL on recovery (mean \pm s.d.: $39.9 \pm 10.3$ v. $38.5 \pm 10.1 \%$ ).

The activity of the 5-HT pump is increased by low cholesterol, as is $\mathrm{Na} / \mathrm{K}$ ATPase activity (Papahajopoulos et al, 1973). Red-cell Na/K ATPase is known to be low in depressed patients, and to increase on recovery (Naylor et al, 1980). Further studies of cholesterol levels in depression with concomitant observation of 5-HT receptor function, optimally by provocation tests, would be of value in clarifying the relationships of cholesterol to 5-HT activity, $\mathrm{Na} / \mathrm{K}$ ATPase activity, and the risk of IHD in depressive illness.

ENGELBERG, H. (1992) Low serum cholesterol and suicide. Lancet, $339,727-729$.

Griffin, B. A., Skinner, E. R. \& Maughan, R. J. (1988) Plasma high density lipoprotein subfractions in subjects with differing coronary risk indices as assessed by plasma lipoprotein concentrations. Atherosclerosis, 70, 165-169.

NaYlor, G. J., SMith, A. H. W., Dick, E. G., et al (1980) Erythrocyte membrane cation carrier in manic-depressive psychoses. Psychological Medicine, 10, 521-525.

Papahajopoulos, D., Cowden, M. \& Kinelberg, H. (1973) Role of cholesterol in membranes. Effects on phospholipid-protein interactions, membrane permeability and enzymatic activity Biochimica et Biophysica Acta, 330, 8-26.

Rabins, P. V., Harvis, K. \& KaVen, S. (1985) High fatality rates of late-life depression associated with cardiovascular disease. Journal of Affective Disorders, 9, 165-167.

Dykebar Hospital

*F. Coulter

Grahamston Road

Paisley PA2 7DE

Argyll and Bute Hospital

Argyll

F. M. Corrigan

B. Mowat

Marischall College

E. R. SKINNER

Aberdeen

*Correspondence
Eye-movement desensitisation to overcome posttraumatic stress disorder

SIR: I read with considerable interest the article by Spector \& Huthwaite (Journal, July 1993, 163, 106-108) because over the past two years or so I have been attempting to use this procedure in my clinical work. Unfortunately, examples of post-traumatic stress disorder usually of a severe nature are all too prevalent in the area where I practise. In general I follow the procedure outlined by Shapiro (1989) but would tend to give more than the 20 saccadic movements in each set.

Initially I experienced some resistance from the patients, so now I would generally give them a short discussion on the association between posttraumatic stress disorder and rapid-eye movement sleep as outlined in the paper by Ross et al (1989). It is a time-consuming procedure both for the patient and the therapist, but in my opinion it can form a valuable part in the treatment of a potentially crippling condition

Ross, R. J., Ball, W. A., Sullivan, K. A., et al (1989) Sleep disturbance as the hallmark of post-traumatic stress disorder. American Journal of Psychiatry, 146, 697-707.

ShAPIRO, F. (1989) Eye movement desensitization; a new treatment for post-traumatic stress disorder. Journal of Behavioural Therapy and Experimental Psychiatry, 20, 211-217.

South Tyrone Hospital

J. B. WALSH

Carland Road

Dungannon

County Tyrone BT71 4AU

\section{How well are 'cured' anorexic nervosa patients?}

SIR: Windauer et al (Journal, August 1993, 163, 195-200) rightly stated that there was little support for my earlier contention (Hsu, 1988) that "for those who recovered from anorexia nervosa, normal weight bulimia nervosa (not major depression) is the most common diagnosis". The preliminary data from our own long-term follow-up study also indicated that eating disorder not otherwise specified (ED NOS) is the most common diagnosis, not bulimia nervosa (Hsu et al, 1992). From the data presented by Windauer et al, I would think that ED NOS is also the most common diagnosis among those who no longer meet criteria for anorexia nervosa.

Hsu, L. K. G. (1988) Outcome of anorexia nervosa: a reappraisal. Psychological Medicine, 18, 807-812. 